УДК 340

DOI https://doi.org/10.51989/NUL.2021.4.32

\title{
ДЖЕРЕЛА АДМІНІСТРАТИВНОГО ПРАВА: ПРОПЕДЕВТИЧНИЙ АСПЕКТ
}

\author{
Калюжна Євгенія Сергіївна, \\ аспірант I курсу \\ Одеського державного університету внутрішніх справ
}

у статті наводиться загальна характеристика джерел адміністративного права. Стверджується, що законодавство й міжнародний договір як джерела адміністративного права найбільш досліджені вітчизняним правознавством. Відзначаються окремі особливості цих джерел. Акцентується на доцільності використання терміну «законодавство» замість терміну «нормативно-правовий акт» і на визначеному колізійними нормами пріоритеті приписів, закріплених у міжнародних договорах щодо вітчизняного законодавства. Указується на досить незначне використання як джерела адміністративного права правового звичаю.

Аналізуються приписи Статуту Міжнародного суду Організації Об'єднаних Націй, які визначають джерела міжнародного права в контексті вітчизняного вчення про джерела права. Зроблено висновок про невикористання в міжнародній практиці як джерела права релігійно-правового тексту (як і в національній системі права, оскільки Україна визначена як світська держава).

Особлива увага зосереджується на таких джерелах, як судовий прецедент, правові принципи й правова доктрина, що обґрунтовується особливістю адміністративно-правової галузі, в межах якої органи публічного адміністрування мають діяти в спосіб і в межах, визначених законом (що є фактором важливості закону як джерела адміністративного права) і природою принципів права, які є основоположними ідеями щодо правових явищ загалом, і адміністративно-правових явищ зокрема.

Відзначається важливість припису, який викладено в Статуті Міжнародного суду, що дозволяє приймати рішення ех aequo et bono, а це відповідає принципу верховенства права й сутності права й указує на важливість принципів права як джерел права загалом, $і$ адміністративного права зокрема.

Резюмується, що джерела є тими засобами об'єктивації адміністративного права, які використовуються для регулювання відповідних суспільних відносин, здійснення адміністративного провадження тощо.

Ключові слова: джерело права, законодавство, міжнародний договір, правовий прецедент, правовий принцип.

\section{Kaliuzhna Yevheniia. Administrative law sources: propaedeutic aspect}

The article provides a general description of the sources of administrative law. It is argued that legislation and international treaty as sources of administrative law are the most studied in domestic jurisprudence. Some features of these sources are noted. Emphasis is placed on the expediency of using the term "legislation" instead of the term "legal act" and on the priority of conflict-of-laws breves fixed in international treaties in relation to domestic legislation. It is indicated the rather insignificant use of legal custom as a source of administrative law.

The breves of the Charter of the International Court of Justice of the United Nations, determining the sources of international law in the context of the domestic doctrine of sources of law, are analyzed. It is concluded that the religious-legal text is not used in international practice as a source of law (as well as in the national law system, since Ukraine is defined as a secular state).

Particular attention is paid to such sources as judicial precedent, law principles and law doctrine, which is based on the peculiarity of the administrative and law field, within which public administrations must act in the manner and within the limits prescribed by the law (which is a factor in the importance of the law as a source of administrative law) and the nature of the principles of law, which are fundamental ideas about law phenomena in general and administrative and law phenomena.

The importance of the breve set out in the Statute of the International Court of Justice is mentioned, which allows for decisions to be made ex aequo et bono, which corresponds to the principle of the rule of law and the essence of law and points to the importance of legal principles as sources of law in general and of administrative law in particular. 
It is summarized that the sources are the means of objectification of administrative law, which are used to regulate the relevant public relations, the implementation of administrative proceedings, and so on.

Key words: source of law, legislation, international treatment, legal precedent, law principle.

Актуальність. Проблематика джерел адміністративного права перманентно перебуває в центрі уваги вітчизняних науковців. Однак більшість робіт не враховує останні напрацювання в правничій сфері, що, на нашу думку, обумовлюється низкою факторів. Так, по-перше, це обумовлюється тим, що в межах загальнотеоретичної правничої науки (теорії держави та права, загальній теорії права) тематика форм права висвітлюється переважно так само, як і в межах радянської юридичної науки (за винятком більш широкої дискусії щодо співвідношення понять «форма права» та «джерело права»). I дотепер основний акцент юриспруденції перенесено на нормативно-правовий акт як джерело права. Багато в чому й донині переважає нормативістське сприйняття права. По-друге, і донині в правничій літературі часто вказується, що Україна належить до романо-германської правової системи, а відтак, основним джерелом права $\epsilon$ нормативно-правовий акт, а правовий прецедент не застосовується. Попри той факт, що практика Європейського суду з прав людини Законом України «Про виконання рішень та застосування практики Європейського суду з прав людини» безпосередньо визнана джерелом права в Україні: «Суди застосовують при розгляді справ Конвенцію та практику Суду як джерело права» [1]. По-третє, процеси глобалізації, визнання юрисдикції Європейського суду з прав людини, намагання України відійти від нормативізму та заснувати свою національну систему права на природному розумінні права суттєво змінили правничу реальність, у тому числі й у контексті джерел права. У такому аспекті варто згадати й soft law, що на сьогодні використовується міжнародною спільнотою майже нарівні 3 hard law. Слід також зазначити й те, що нині відбувається трансформація теорії людських прав, зокрема в контексті виокремлення горизонтального виміру (якщо вертикальний вимір обумовлював розгляду лише держави як зобов'язаної сторони, то уже прийнято низку міжнародно- правових документів, які поширюють обов'язок визнання та захисту людських прав на бізнес). А саме людські права, які визначають зобов'язання суб'єктів, слугуючи фактором регулювання їх поведінки.

Таким чином, проблематика джерел права, і зокрема джерел адміністративного права, є вкрай важливою та потребує свого розв'язання.

Аналіз останніх досліджень і публікацій. Як було відзначено, проблематика джерел адміністративного права не $\epsilon$ малодослідженою. У правничій літературі $\epsilon$ значна кількість робіт, присвячених цій тематиці. Зокрема, слід згадати праці таких вітчизняних вчених, як В. Авер'янов, О. Андрійко, Ю. Битяк, А. Галай, В. Доненко, О. Констатий, М. Корнієнко, $€$. Легеза, Б. Логвиненко, Р. Миронюк, Т. Мінка, В. Решота, Н. Рибалка, М. Хиля та інші.

Однак у роботах не завжди враховуються вказані нами вище аспекти. Так, наприклад, О. Константий відзначив, що «правова система України включає у себе в якості джерел адміністративного права нормативно-правові акти державних органів, органів місцевого самоврядування, міжнародно-правові договори України і рішення Конституційного Суду України, як специфічні (нормативно-допоміжні) джерела» [2, с. 6].

Як бачимо, автором зроблено акцент на тих джерел, що виокремлюються переважно в межах нормативістьского підходу до розуміння права з виокремленням рішень органу конституційної юстиції, однак, сам автор відзначає на специфічності останнього джерела (наголосимо, що в правничій науці дискусійним $є$ питання сутності актів органів конституційного контролю: їх слід сприймати лише як інтерпретаційно-правові акти чи й як акти право творення, зокрема в контексті негативного законодавця).

Слід згадати і дисертаційне дослідження М. Хиля, присвячену тематиці нормативно-правового акту як джерела адміністративного права, у якій серед іншого 
автором відзначає, що «сучасна концепція джерел адміністративного права надає особливе значення нормативно-правовим актам як регуляторів публічно-правових відносин» [3, с. 1]. Водночас, на думку автора, система цих джерел $\epsilon$ «Складною, динамічною, багатофункціональною, цілеспрямованою та керованою складовою частиною системи права України» [3, с. 12]. Однак не зрозуміло, що мається на увазі під багатофункціональністю джерел адміністративного права, їх цілеспрямованістю (особливо, коли йдеться не про волю та діяльність людини) і керованістю. До того ж незрозумілим залишається місце принципів у цій системі та їх інтерпретації, виходячи з виокремлення автором принципів права й норм-принципів [3, с. 12].

Не можна не згадати й дисертацію В. Решоти, в якій висвітлюється застосування джерел адміністративного права в українському судочинстві [4]. Цілком слушною $\epsilon$ думка вказаного автора, яка наголошує на актуальності обраної нами теми дослідження. Так, автором серед іншого відзначено, що, хоча проблематика джерел адміністративного права «висвітлюється в навчальній літературі 3 адміністративного права, однак ґрунтовні монографічні дослідження з цієї проблеми вже тривалий час не проводилися. Окремі види джерел адміністративного права були предметом наукових пошуків і досліджень, проте це не дозволило комплексно проаналізувати всю систему джерел адміністративного права України, розкрити зв'язки між елементами цієї системи» [4, с. 20]. I, хоча науковець відзначає про важливість такого джерела, як правовий прецедент, він дійшов висновку, що «серед дослідників адміністративного права традиційно термін «джерело права» розглядається у формально-юридичному значенні, де основний акцент робиться на позитивному праві <...>» [4, с. 21]. 3 одного боку, із цим важко не погодитись, зважаючи на те, що, як ми також вказали, і донині в національній системі права превалює юридичний нормативізм (на задекларовану прихильність до цінностей природно-правової школи). А з іншого, - ураховуючи конституційні положення про людину як цінність, про права як той чинник, що визначає, наприклад, діяльності держави, про правову державу й верховенство права, не можна не вказати на необхідність переосмислення такого підходу.

Метою статті $\epsilon$ системне висвітлення джерел адміністративного права.

Виклад основного матеріалу. Перед висвітленням предмету пізнання варто наголосити, що найбільш усталеним у вітчизняному правознавстві $€$ розуміння джерел права таким чином. Як вказує колектив авторів «більшість учених-юристів джерело права ототожнюють із формою виразу права. Так, наприклад, П. Рабінович прямо говорить про те, що джерела юридичних норм відбиваються поняттям форми права (зовнішньої); В. Хропанюк джерело права визначає як спосіб виразу й закріплення правових норм, правовий термін, який використовується для позначення зовнішньої форми виразу правових норм <...>» [5, с. 199].

Саме в такому аспекті поняття «джерело права» розглядається й у нашій роботі.

Відзначимо, що в навчальній літературі із загальної теорії права як джерела права виокремлюють: правовий звичай; правовий прецедент; нормативний договір; правову доктрину; релігійно-правовий текст; загальні принципи права; нормативно-правовий акт [5, с. 200-201].

Водночас, висвітлюючи предмет дослідження не можна не згадати й положення Статуту Міжнародного суду, ст. 38 якого містить перелік джерел, які використовує вказаний Суд:

«а) міжнародні конвенції <...>;

б) міжнародний звичай як доказ загальної практики, визнаної як право;

в) загальні принципи права, визнані цивілізованими націями;

г) <..> судові рішення та доктрини найбільш кваліфікованих фахівців із публічного права різних націй <...>» [6].

Отже, як цілком правильно вказує вітчизняний правник А. Кучук, аналіз правничої літератури й приписів Статуту Міжнародного суду дозволяє дійти висновку, що релігійно-правовий текст не віднесено до джерел міжнародного права на універсальному рівні [7, с. 25].

Зважаючи на означене, в межах цього дослідження ми не будемо розглядати таке джерело права як релігійно-правовий текст (особливо у контексті визнання України світською державою). 
Окрім цього доцільно також відзначити, що доволі обмеженим в національному праві $\epsilon$ використання такого джерела права як правовий звичай. На можливість використання такого джерела вказується в Сімейному кодексі України й Цивільному кодексі України. Однак, варто погодитись із С. Мойсак відносно того, що правовий звичай як джерело адміністративного права має дуже обмежену сферу використання, а отже, застосовується суто у виняткових випадках у порядку, що визначено законодавством [8, с. 10]. Тому це джерело права не розглядається в межах роботи.

Слід вказати, що деякі джерела права $\epsilon$ досить висвітленими вітчизняним правознавством, а тому ми не зосереджуємо на них увагу. Це такі джерела права (відповідно, і адміністративного права), як:

- законодавство (саме цей термін переважно використовується в межах західної концепції права; поняття «нормативноправовий акт не властиве навіть сім'ї континентального права. Саме тому ми послуговуємось терміном «законодавство»). Водночас необхідно наголосити, що не будь-який закон чи підзаконний акт наділяється нормативністю. Таку якість має лише той з них, що є справедливим (як це випливає з рішень Конституційного Суду України, маємо на увазі, зокрема, рішення у справі про призначення судом більш м'якого покарання, в якому було відзначено таке: «<...> закони, які за своїм змістом мають бути проникнуті передусім ідеями соціальної справедливості, свободи, рівності тощо. <...> Справедливість - одна з основних засад права, $\epsilon$ вирішальною у визначенні його як регулятора суспільних відносин, одним із загальнолюдських вимірів права» [9], має відповідати верховенству права, бути юридично визначеним (як це випливає з рішень Європейського суду з прав людини. Так, у справі Волохи проти України Європейський суд s3 прав людини відзначив таке: «Суд завжди дотримувався думки, що словосполучення «згідно із законом» <...> пов'язане 3 вимогою якості «закону», тобто вимогою дотримання принципу «верховенства права»[10];

- нормативний договір (зважаючи на предмет нашого дослідження йдеться передусім про міжнародний договір), хоча варто відзначити, що відповідно до Конституції України таке джерело $є$ частиною національного законодавства. Водночас значна частина кодифікованих актів національного права передбачає колізійну норму, яка установлює пріоритет норм, що викладені саме в міжнародних договорах,

Водночас варто також наголосити на важливості припису, викладено в ч. 2 ст. 38 Статуту Міжнародного суду, відповідно до якого Суд може приймати рішення ex aequo et bono [6]. Наведене цілком узгоджується 3 принципом верховенства права й відповідає сутності права. Отже, зумовлює необхідність акцентування на таких джерелах права, як принципи права й певною мірою правова доктрина (відзначимо, що верховенство права також може розглядатись як доктрина).

Таким чином, у наступній частині дослідження ми розглянемо такі джерела адміністративного права, як судовий прецедент, принципи права й правова доктрина.

Черговий раз відзначимо той факт, що чинним законодавством практика Європейського суду з прав людини визнана джерелом права в Україні. Це положення повною мірою стосується і адміністративно-правової сфери.

Доцільно також відмітити, що відповідно до ч. 2 ст. 6 Кодексу адміністративного судочинства України, яка визначає застосування національним судом принципу верховенства права, «Суд застосовує принцип верховенства права з урахуванням судової практики Європейського суду з прав людини» [11]. Наведене положення зобов'язує адміністративні суди вивчати усталену практику страсбурзького суду та керуватися нею при здійсненні правосуддя. Інакше неможливо буде реалізувати принцип верховенства права. Додамо, що відповідно до ч. 5 ст. 186 означеного Кодексу «під час закритих нарад суддя має право звертати увагу сторони на судову практику в аналогічних спорах <...> [11].

До окремих аспектів застосування судового прецеденту в адміністративному судочинстві можна певною мірою віднести й положення про типові та зразкові справи. 
Наведене дозволяє вести мову про судовий прецедент як важливе джерело адміністративного права.

Наступні два джерела адміністративного права - принципи права й правова доктрина, - на нашу думку, дуже тісно пов'язані між собою, хоча звісно не співпадають повною мірою. Такий зв'язок обумовлюється особливістю адміністративноправової галузі, в межах якої органи публічного адміністрування мають діяти у спосіб та в межах, визначених законом (що є фактором важливості закону як джерела адміністративного права) та природою принципів права, які $€$ основоположними ідеями щодо правових явищ загалом та адміністративно-правових явищ. При цьому варто наголосити, що у вітчизняному правознавстві принципи права сприймаються і до сьогодні через призму юридичного нормативізму, що обумовлює їх інтерпретацію лише через формальне відбиття у тексті закону (що ставить їх у залежність від прескриптивного тексту). Водночас принципи права - це основоположні ідеї, що відбивають сутність цього соціального феномену. Отже, насамперед вони знаходять відбиття саме через їх осмислення вченими-правниками у правничій літературі, становлячи складову частину правової доктрини.

Слід погодитись з А. Кучуком і С. Перепьолкіним відносно того, що принципи права слід інтерпретувати як такі правила поведінки, що «закріплюють основні (відправні) начала, відбивають ідеї справедливості, рівності, свободи й вирізняються імперативністю, об'єктивністю, стабільністю, комплексністю, рівнозначністю» $[12$, c. 26].
Досить яскравим прикладом значущості принципів права для адміністративно-правової галузі $\epsilon$ верховенство права. Цей принцип має важливу роль для національної системи права. Відповідно до ст. 8 Конституції України «В Україні визнається та діє принцип верховенства права» [13].

Цей принцип закріплено й у Кодексі адміністративного судочинства України. Верховенство права $€$ однією із цінностей європейського співтовариства, вимогою належного урядування. Водночас відсутній єдиний документ, у якому 6 розкривався зміст верховенства права. Застосовуючи цей принцип, органи публічної влади мають керуватися практикою Європейського суду з прав людини. Важливим засобом пізнання верховенства права $\epsilon$ правнича література, що обумовлює зв'язок принципів права з правовою доктриною. Додамо, що вперше концептуальне оформлення цей принцип отримав у праці А. Дайсі.

Висновки. Таким чином, джерела $\epsilon$ тими засобами об'єктивації адміністративного права, що використовуються для регулювання відповідних суспільних відносин, здійснення адміністративного провадження тощо. Найбільш важливе значення серед джерел адміністративного права мають адміністративне законодавство, міжнародні договори, правовий прецедент, принципи права та правова доктрина. Таке джерело права, як правовий звичай, має дуже обмежене використання для регулювання управлінських відносин. Фактично не використовується як джерело права релігійно-правовий текст (не вказано це джерело та як засіб розв'язання правових конфліктів Міжнародним судом ООН).

\section{ЛITEPAТУРА:}

1. Про виконання рішень та застосування практики Європейського суду з прав людини : Закон України від 23 лютого 2006 року № 3477-IV / Верховна Рада України. Відомості Верховної Ради України. 2006. № 30. Ст. 260.

2. Константий О.В. Джерела адміністративного права України : автореф. дис. ... канд. юрид. наук : 12.00.07. Харків, 2000. 16 с.

3. Хиля М.М. Нормативно-правові акти як джерела адміністративного права України : автореф. дис. ... канд. юрид. наук : 12.00.07. Тернопіль, 2019. 20 с.

4. Решота В.В. Застосування джерел адміністративного права в судочинстві України : автореф. дис. ... д-ра юрид. наук : 12.00.07. Львів, 2019. 36 с.

5. Теорія держави і права : підручник / кол. авт. ; кер. авт. кол. канд. юрид. наук, проф. Ю.А. Ведєрніков. 3-є вид. перероб. і доп. Дніпро : Дніпроп. держ. ун-т внутр. справ ; Ліра ЛТД, 2016. 480 с. 
6. Statute of the international Court of justice. URL: http://www.icj-cij.org/documents/index. php?p1 $=4 \& p 2=2 \& p 3-=0 \#$ CHAPTER_II.

7. Кучук А.М. Джерела права: міжнародний і теоретико-правовий аспекти. Альманах міжнародного права. 2016. № 14. С. 23-30.

8. Мойсак С.М. Акти управління в системі джерел адміністративного права України : автореф. дис. ... канд. юрид. наук : 12.00.07. Одеса, 2011. 20 с.

9. Рішення Конституційного Суду України у справі за конституційним поданням Верховного Суду України щодо відповідності Конституції України (конституційності) положень статті 69 Кримінального кодексу України (справа про призначення судом більш м'якого покарання) № 15-рп/2004 від 2 листопада 2004 року / Конституційний Суд України. URL: http:// zakon.rada.gov.ua/cgi-bin/laws/main.cgi?nreg=v015p710-04.

10. Волохи проти України. Рішення Європейського суду з прав людини від 2 листопада 2006 року (заява № 23543/02). База даних «Законодавство України». URL: https:// zakon.rada.gov.ua/laws/show/974_138\#Text.

11. Кодекс адміністративного судочинства України : Закон України від 6 липня 2005 року № 2747-IV / Верховна Рада України. Відомості Верховної Ради України. 2005. № 35-36, № 37. Ст. 446.

12. Кучук А.М., Перепьолкін С.М. Принципи права як категорія внутрішньодержавного й міжнародного права. Право і суспільство. 2015. № 3 (3). С. 22-26.

13. Конституція України : Закон України від 28 червня 1996 року № 254к/96-ВР / Верховна Рада України. Відомості Верховної Ради України. 1996. № 30. Ст. 141. 